\title{
Esophagectomy with gastroplasty in advanced megaesophagus: late results of omeprazole use
}

\section{Esofagectomia com gastroplastia no megaesôfago avançado: análise tardia da importância do uso do omeprazol}

\author{
Celso de Castro Pochinı, TCBC-SP1; Danilo Gagliardi,TCBC-SP1; Roberto SaAd Júnior, TCBC-SP'; Ruy França de Almeida, \\ TCBC-SP'; PAULO ROBERTO CORSI, TCBC-SP'
}

A $B$ S T R A C T

\begin{abstract}
Objective: To analyze the late results of advanced Chagasic megaesophagus treatment by esophagectomy associated with the use of proton pump inhibitor (omeprazole) as for the incidence of esophagitis and Barrett's esophagus in the remaining stump. Methods: We studied patients with advanced megaesophagus undergoing esophagectomy and transmediastinal esophagogastroplasty. Patients were divided into three groups: A (20) with esophageal replacement by full stomach, without the use of omeprazole; B (20) with esophageal replacement by full stomach, with omeprazole $40 \mathrm{mg} /$ day introduced after the first postoperative endoscopy and maintained for six years; and C (30) with esophageal replacement by gastric tube with use of omeprazole. Dysphagia, weight loss and BMI were clinical parameters we analyzed. Upper gastrointestinal endoscopy was performed in all patients, and determined the height of the anastomosis, the aspect of the mucosa, with special attention to possible injuries arising from gastroesophageal reflux, and the patency of the esophagogastric anastomosis. Results: We studied 50 patients, 28 males (56\%) and $22(44 \%)$ females. All underwent endoscopy every year. In the first endoscopy, erosive esophagitis was present in nine patients (18\%) and Barrett's esophagus, in four (8\%); in the last endoscopy, erosive esophagitis was present in five patients ( $8 \%)$ and Barrett's esophagus in one ( $2 \%)$. When comparing groups B and $C$, there was no evidence that the manufacturing of a gastric tube reduced esophagitis and Barrett's esophagus. However, when comparing groups $A$ and $C$, omeprazole use was correlated with reduction of reflux complications such as esophagitis and Barrett's esophagus ( $p<0.005)$. Conclusion: The use of omeprazole $(40 \mathrm{mg} / \mathrm{day})$ reduced the onset of erosive esophagitis and Barrett's esophagus during the late postoperative period.
\end{abstract}

Key words: Chagas Disease. Esophagitis. Barrett Esophagus. Esophagectomy. Omeprazole.

\section{INTRODUCTION}

$\mathrm{T}$ he esophagus is the organ most commonly affected by Chagas disease in the digestive tract. The resulting condition is the megaesophagus, characterized by dilation and lengthening of the organ body, progressive, functional dysphagia, the pathological substrate being the damage to the intermuscular plexus by the Trypanosoma cruzi,2.

Chagas is one of the most common parasitic diseases in Latin America, with a commitment of 670,000 lives / year and annual cost of morbidity and death estimated at more than eight billion dollars in 2000. Chagas disease affects eight million people in America Latin ${ }^{3,4}$. The first proposal for the surgical treatment of achalasia was made by Gottstein, which indicated cardiomyotomy 5 . However, it was Heller who consecrated the procedure, with section of the muscles in the anterior and posterior aspects of the esophagus $^{6}$. Later, others came to perform it only in the anterior asppect ${ }^{7}$. However, achalasia in its most advanced stage (grade IV), requires a larger surgical procedure, the treatment of choice being the removal of the diseased organ, ie, esophagectomy ${ }^{8-11}$.

In Brazil, around 1960, Câmara Lopes and Ferreira Santos successfully performed the first subtotal esophagectomy by right thoracotomy, followed by gastroplasty in two and one times, respectively ${ }^{12,13}$

From the 1970s on, the cervico-abdominomediastinal route gained preference in the treatment of Chagas megaesophagus. Eugenio Ferreira et al. spread the technique in our country, 28 patients underwent subtotal esophagectomy through esophagus extraction ${ }^{14}$. Subsequently, Pinotti et al. advocated section of the diaphragm from the hiatal ring to the xiphoid process, providing more security and improving the procedure results ${ }^{15-18}$.

1. Departamento de Cirurgia da Faculdade de Ciências Médicas da Santa Casa de São Paulo, SP, Brasil. 
Aquino et al. caused surprised by performing esophagectomy through esophageal mucosal resection (removal only of the mucosal cylinder), with low complications rate ${ }^{19-21}$.

Although not appreciated by many surgeons, Rocha et al., following 48 patients undergoing esophagectomy and gastroplasty with cervical anastomosis, found severe chronic gastritis, as well as the presence of a "bile lake" in the gastric antrum, with endoscopic appearance similar to alkaline reflux gastritis ${ }^{22}$. Four years later, studying 48 patients who underwent subtotal esophagectomy with esophagogastroplasty, they found Barrett's esophagus in four patients, the latest one at 18 months after the operation ${ }^{23}$.

The reflux of gastric juice and bile fluid are important factors in the genesis of Barrett's esophagus, there being a direct correlation between the metaplastic segment and the time the esophagus is exposed to $\mathrm{pH}<4^{24}$

Rocha et al. Studied 101 patients who underwent transmediastinal esophagectomy with gastroplasty, having found $70 \%$ erosive esophagitis and $57 \%$ columnar epithelialization, besides two cases of cancer in the remaining esophageal stump ${ }^{25}$.

Oberg proved that despite truncal vagotomy, there was no long-term suppression of acid reflux. Corroborating this statement, Rocha et al. described erosive esophagitis and Barrett's esophagus in patients undergoing esophagectomy with gastroplasty. They suggested that longterm treatment with proton pump inhibitor could avoid such complications $^{26}$

Prophylactic treatment done with the restoration of transit through a gastric tube with proton pump inhibitor (PPI) and annual endoscopic follow-up has been the guidance of experts to reduce reflux complications ${ }^{26-28}$.

This research aims to analyze the late results of advanced Chagasic megaesophagus treatment by esophagectomy associated with PPIs (omeprazole), targeted at the incidences of esophagitis and Barrett's esophagus in the remaining stump.

\section{METHODS}

We studied 50 patients with megaesophagus treated at the clinic of the Esophagus Group of the Departamento de Cirurgia da Faculdade de Ciências Médicas da Santa Casa de São Paulo, in the period from April 26, 1990 to January 08, 2011. They were 22 (44\%) women and 28 $(56 \%)$ men. The age ranged from 24 to 79 years, the average being 49 .

The diagnosis was made clinically, by serological test for Chagas disease, by radiological examinations and by esophageal eletromanometry. Barium swallow was performed with Philips-Challenge N $800 \mathrm{HF}$ apparatus after the ingestion of $100 \mathrm{ml}$ of barium sulphate diluted in $200 \mathrm{ml}$ of water at three positions $180 \mathrm{~cm}$ distant from the bulb with films at ten seconds, five minutes and 30 minutes. The eletromanometry was made with a six channel computerized polygraph (Synectics - Sweden), EMC-R catheter under pneumo-hydraulic capillary infusion, with flow of $0.6 \mathrm{ml} / \mathrm{min} / \mathrm{channel}$. Patients with impaired esophageal body contraction were characterized as having megaesophagus.

Patients underwent Machado-Guerreiro complement fixation test and indirect hemagglutination or immunoenzymatic reaction (ELISA) for the confirmation of Chagas disease $\mathrm{e}^{29-31}$.

We included patients with achalasia with organ dilation largest than $10 \mathrm{~cm}$ (grade IV) at the esophagus radiological contrast examination; patients with achalasia with electromanometry revealing absence of lower esophageal sphincter relaxation and synchronous contractions of low amplitude of the esophageal body $(<15$ $\mathrm{mmHg}$ ).

We have carried out two types of operations: resection of the esophagus by esophageal extraction and resection by trans-hiatal dissection. The restoration of the transit was made with the full stomach in 20 patients and with a gastric tube of greater curvature in 30 patients (Figures 1 and 2). The cervical esophagogastric anastomosis was manual, by left lateral cervicotomy positioned at the level of the sternal notch, about $15 \mathrm{~cm}$ from the upper dental arch or $4 \mathrm{~cm}$ from the cricopharyngeal muscle (pharyngoesophageal transition). Truncal vagotomy and pyloroplasty were performed in all patients.

Dysphagia, weight loss and body mass index were clinical parameters analyzed. Upper gastrointestinal endoscopy was performed in all patients. We determined the height of the anastomosis, the aspect of the mucosa, with special attention to possible injuries arising from

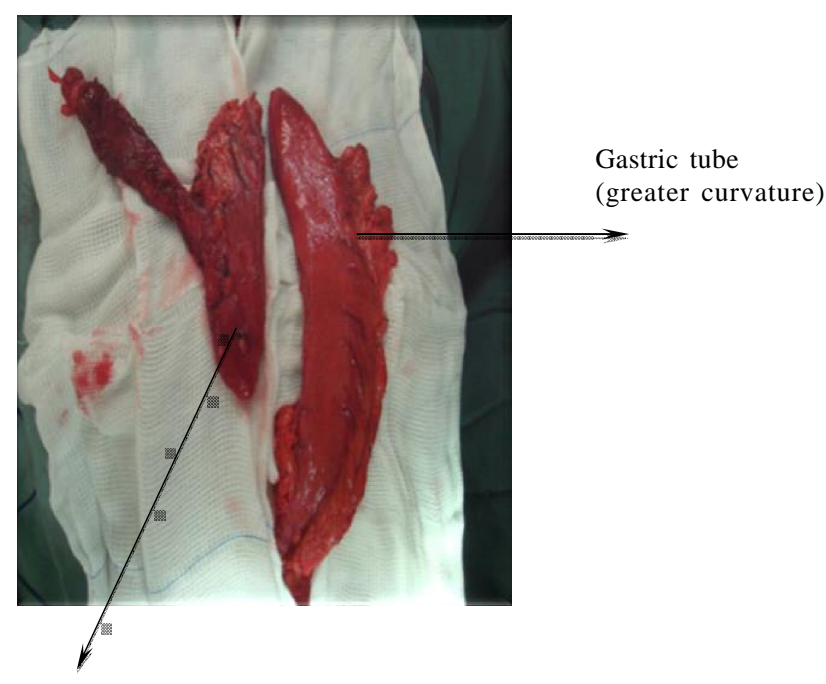

Resected distal esophagus and gastric lesser curvature.

Figure 1 - Gastric tube with resection of lesser curvature. 


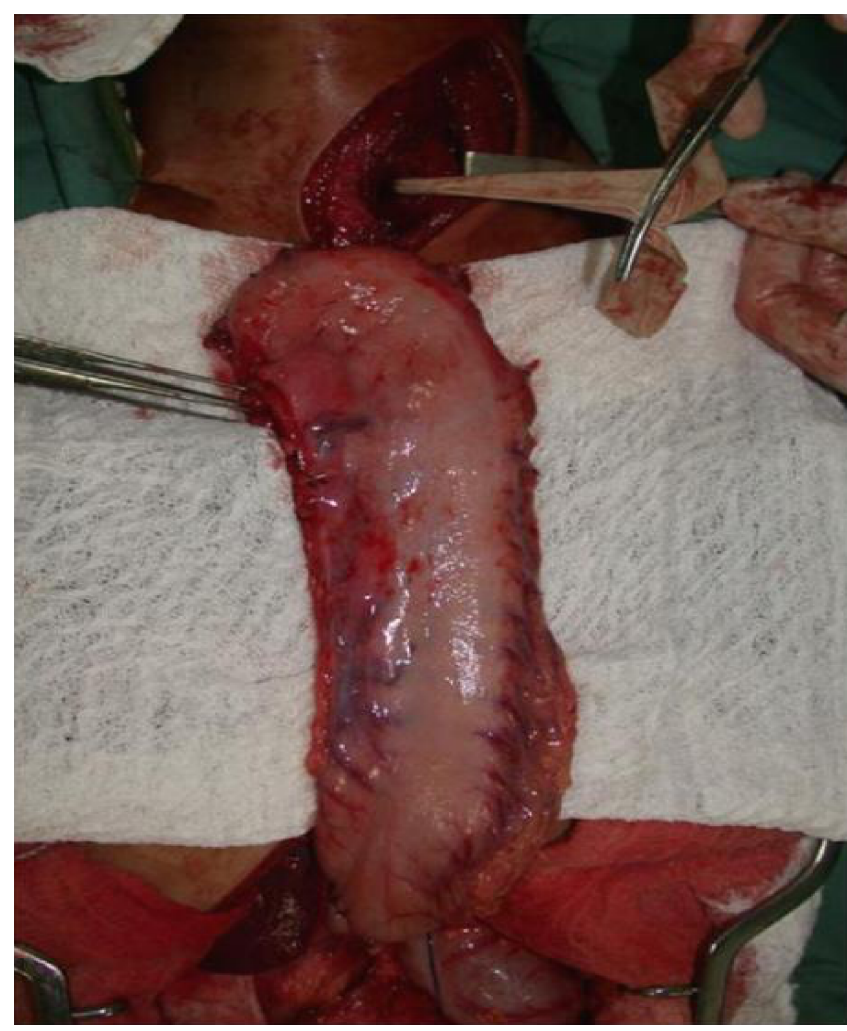

Figure 2 - Reconstitution of transit post-esophagectomy. Total stomach.

gastroesophageal reflux, and the patency of the esophagogastric anastomosis.

We harvested three fragments from the esophagus and three from the stomach two $\mathrm{cm}$ above and two below the anastomosis, after prior staining with methylene blue. The fragments were fixed in 3.7\% formalin and stained with hematoxylin-eosin for subsequent histological analysis.

The use of proton pump inhibitor was done at a dose of $40 \mathrm{mg} /$ day for all patients undergoing esophagectomy operated from 2006 on. Since 2006, the transit reconstitution of all patients comprised an enlarged proximal gastrectomy (gastric tube). Three groups were formed: Group A - Operated from 1990 to 2006 with full stomach esophageal replacement, without the use of omeprazole during this period, and the first postoperative endoscopy performed in 2006; Group B - operated from 1990 to 2006 with esophageal replacement through full stomach, without the use of omeprazole during that period, and after the first postoperative endoscopy in 2006, intiaintg omeprazole use, which lasted six years until 2011; Group C - operated between 2006 and 2011 with esophageal replacement with gastric tube (enlarged proximal gastrectomy), with use of omeprazole during this period, and the first endoscopy performed in 2006.

For the descriptive analysis, we used position measurements for continuous variables and frequency for categorical variables. For comparison groups and times of endoscopy results we used the GEE model (Generalized Estimating Equation Model). To compare weight loss between groups we used analysis of variance (ANOVA). To compare dysphagia and heartburn between groups we used the Chi-square test and, when necessary, the Fisher's exact test. We deemed significant a $p$ value $\leq 0.05$.

\section{RESULTS}

We found no patient with severe dysphagia; $13(26 \%)$ patients had dysphagia (mild), of whom $92 \%$ had no aspiration or weight loss. As for the remaining $37(74 \%)$, they did not have such complaint after esophagectomy.

The records of the current weight and height allow us to state that 39 (78\%) patients were healthy (normal weight). As for the other 11: 16\% were overweight and $6 \%$ were malnourished after esophagectomy. Ten patients (21\%) had heartburn after the surgical procedure.

The first endoscopy was performed in 2006 and the last in 2011. In the first endoscopy erosive esophagitis was present in nine (18\%) patients and Barrett's esophagus in four (8\%); during the last endoscopy we observed erosive esophagitis in four (8\%) patients and Barrett's esophagus in one $(2 \%)$ (Table 1$)$.

There was a statistically significant difference $(p=0.002$ ) between groups $A$ and $C$ in relation to the results of digestive endoscopy (Table 2 ). There was no statistically significant difference $(p=0.416)$ between groups $B$ and $C$ regarding the outcome of digestive endoscopy (Table 3 ).

\section{DISCUSSION}

Considering our findings regarding the clinical aspects - dysphagia, heartburn, aspiration, weight loss and nutritional status -, we can say that esophagectomy in advanced megaesophagus provides good quality of life in

Table 1 - Distribution of patients according to treatment with PPI after esophagectomy.

\begin{tabular}{lrr}
\hline Total Group & \multicolumn{2}{c}{50} \\
& patients \\
& $\%$ \\
\hline Endoscopy (First)-2006 & 37 & 74 \\
Absent & 9 & 18 \\
Erosive Esophagitis & 4 & 8 \\
Barrett & & \\
Endoscopy (Last)-2011 & 45 & 90 \\
Absent & 4 & 8 \\
Erosive Esophagitis & 1 & 2 \\
Barrett & \\
\hline
\end{tabular}

Source: Santa Casa de Misericórdia de São Paulo (1990 to 2011). 
Table 2 - Distribution of Endoscopies' results (First and Last) after esophagectomy for groups A and $\mathrm{C}$.

\begin{tabular}{lrrc}
\hline Group & A & C & $p$ \\
\hline Endoscopy (First) & & & \\
Absent & 10 & 27 & 0.002 \\
Erosive Esophagitis & 6 & 3 & \\
Barrett & 4 & 0 & \\
Endoscopy (Last) & & & \\
Absent & 10 & 29 & \\
Erosive Esophagitis & 6 & 1 & \\
Barrett & 4 & 0 & \\
\hline Source & &
\end{tabular}

Source: Santa Casa de Misericórdia de São Paulo (1990 to 2011).

Table 3 - Distribution of Endoscopies' results (First and Last) after esophagectomy for groups B and $\mathrm{C}$.

\begin{tabular}{lrrc}
\hline Group & B & C & $p$ \\
\hline Endoscopy (First) & & & \\
Absent & 16 & 27 & 0.416 \\
Erosive Esophagitis & 3 & 3 & \\
Barrett & 1 & 0 & \\
Endoscopy (Last) & & & \\
Absent & 16 & 29 & 0.143 \\
Erosive Esophagitis & 3 & 1 & \\
Barrett & 1 & 0 & \\
\hline
\end{tabular}

Source: Santa Casa de Misericórdia de São Paulo (1990 to 2011).

the short and medium term, especially as for the nutritional aspect $\mathrm{t}^{11,20,21,28,32}$

It is worth remembering that $80 \%$ of patients were asymptomatic and did not complain of heartburn. In the long-term monitoring, the presence of erosive esophagitis and Barrett's esophagus brought reflections.

It was believed that truncal vagotomy associated to pyloroplasty and the use of the entire stomach in the transit reconstitution was sufficient to reduce gastric acidity, minimizing reflux. Considering that in these patients, basal and stimulated acid secretion is lower than that found in normal subjects, and the right colon may be affected by the disease, reconstitution with the stomach initially appeared to be a great option. However, the follow-up of patients submitted to esophagectomy with this type of reconstitution and without the use of proton pump inhibitor (PPI) may show disastrous complications, such as Barrett's esophagus and esophageal stump cancer ${ }^{25,33-35}$

From the first year after surgery, the pepsinogen levels and acid secretion, both at baseline and under stimulus, increase despite truncal vagotomy and pyloroplasty. As a consequence, there has been found up to $20 \%$ esophagitis in the cervical esophageal stump during the first year after surgery, and approximately $70 \%$ in the seventh year, and the presence of Barrett's esophagus in the cervical stump in up to $27.7 \%$ of cases, which is more serious $^{26,34}$. Of course, the destruction of reflux containment mechanisms (loss of inferior esophageal sphincter mechanism, cardia and pylorus), promote mixed reflux (acid and bile), extremely harmful to the esophageal mucosa ${ }^{36,37}$.

In an attempt to reduce acid reflux, an option has been made for the resection of the lesser curvature of the stomach, reducing the population of acid-producing parietal cells, and manufacturing of a gastric tube ${ }^{25,28}$. Results have not improved, though.

When more specifically considering complications arising from the duodenogastric reflux (esophagitis and Barrett's esophagus), we found no statistically significant correlation $(p=0.143)$ between groups $B$ and $C$. We remember that both received PPIs (omeprazole) at the same dosage, but differed in that Group B had the reconstitution with full stomach and Group $C$ had the gastric tube. Thus, we cannot say with certainty that the enlarged proximal gastrectomy contributed to the reduction of esophagitis and Barrett in our patients. Other authors also found the occurrence of esophagitis and Barrett's esophagus in the esophageal stump of patients with gastric tube, since its vertical position is maintained, facilitating rapid gastric emptying, as well as duodenogastric reflux $x^{34,35,38,39}$.

We conducted esophagectomy with enlarged proximal gastrectomy (gastric tube) and yearly endoscopy, as experts recommend. We noted that Group A, which was devoid of PPI, showed a greater number of complications due to acid and bile reflux ${ }^{25,27,28,40}$. In addition, our statistical calculations emphasize the use of omeprazole (Group C) as the most significant independent variable correlated with reduced complications of mixed reflux (erosive esophagitis and Barrett's esophagus - Group A) in the univariate analysis, showing a statistically significant difference (Table 2).

We understand that the use of PPIs in continuous monitoring of patients submitted to esophagectomy is essential, and that a dosage of $40 \mathrm{mg} /$ day can reduce the appearance of erosive esophagitis and Barrett in the remaining stump.

We stress the utmost importance of the clinical follow-up and annual endoscopic exam of patients undergoing esophagogastroplasty, combined with the continued use of proton pump inhibitors, beginning in the early postoperative period in an attempt to decrease tumor development in the remaining esophageal stump 26,33,35,40-43.

The results obtained in this study, with 50 Chagas megaesophagus patients, support the conclusion that the use of omeprazole ( $40 \mathrm{mg} /$ day) reduced the onset of erosive esophagitis and Barrett's esophagus during the late postoperative period. 


\title{
R E S U M O
}

\begin{abstract}
Objetivo: analisar os resultados tardios do tratamento do megaesôfago chagásico avançado através da esofagectomia associada ao IBP (omeprazol), com vistas à incidência de esofagite e esôfago de Barrett do coto esofagiano remanescente. Métodos: foram estudados pacientes com megaesôfago avançado submetidos à esofagectomia e à esofagogastroplastia transmediastinal posterior. Os pacientes foram distribuídos em três grupos: A (20) com substituição esofagiana por meio do estômago total, sem o uso do omeprazol; B (20) com substituição esofagiana por meio do estômago total, sem o uso do omeprazol durante este período; após a primeira endoscopia, realizada no pós-operatório, foi introduzido IBP (omeprazol 40mg/dia) e mantido por seis anos; e C (30) com substituição esofagiana por meio do tubo gástrico com uso do omeprazol. A disfagia, a perda ponderal e o IMC foram os parâmetros clínicos analisados. A endoscopia digestiva alta foi realizada em todos os pacientes. Foi determinada a altura da anastomose, a aparência do aspecto da mucosa, com especial atenção para possíveis lesões oriundas de refluxo gastresofágico, a patência da anastomose esofagogástrica. Resultados: na primeira endoscopia, a esofagite erosiva esteve presente em nove pacientes (18\%) e o esôfago Barrett, em quatro (8\%); na última endoscopia, a esofagite erosiva esteve presente em quatro pacientes (8\%) e o esôfago de Barrett em um (2\%). Comparando-se os grupos B e C, não houve redução da esofagite e do esôfago de Barrett. Porém, comparando-se os grupos $A$ e $C$, houve redução de complicações do refluxo, como esofagite e o esôfago de Barrett ( $p<0,005)$. Conclusão: os resultados obtidos permitem concluir que o uso de omeprazol (40mg/dia) reduziu o aparecimento de esofagite erosiva e esôfago de Barrett no decorrer do pós-operatório tardio.
\end{abstract}

Descritores: Doença de Chagas. Esofagite. Esôfago de Barrett. Esofagectomia. Omeprazol.

\section{REFERENCES}

1. Köberle F. Chagas' disease and Chagas' syndromes: the pathology of American trypanosomiasis. Adv Parasitol. 1968;6:63-116.

2. Coura JR, Borges-Pereira J. Chagas disease: 100 years after its discovery. Acta Trop. 2010;115(1-2):5-13.

3. Rassi A Jr, Rassi A, Marin-Neto JA. Chagas disease. Lancet. 2010;375(9723):1388-402

4. Lescure FX, Le Loup G, Freilij H, Develoux M, Paris L, Brutus L, et al Chagas disease: changes in knowledge and management. Lancet. 2010;10(8):556-70.

5. Gottstein G Technik und Klinik der Oesophagoskopie. Mitt Grenzgeb Med Chir. 1901;8:57-152.

6. Heller E. Extramuköse cardioplastik beim chronischen cardiospasmus mit dilatation des oesophagus, Mitt Grenzgeb Med Chir. 1914;27:141-9.

7. Ellenbogen G. Megaesôfago não avançado. Tratamento pela cardiomiotomia associada à esofagogastrofundopexia. Avaliação clínica, morfológica e funcional dos seus resultados [tese]. São Paulo: Universidade de São Paulo, Faculdade de Medicina; 1979.

8. Orringer MB, Marshall B, Chang AC, Lee J, Pickens A, Lau CL. Two thousand transhiatal esophagectomies: changing trends, lessons learned. Ann Surg. 2007;246(3):363-72; discussion 372-4.

9. Crema E, Cruvinel LAF, Werneck AM, Oliveira RM, Silva AA. Correlação manométrico-radiológica e sua importância no tratamento cirúrgico do megaesôfago chagásico. Rev Soc Bras Med Trop. 2003;36(6):665-9.

10. Herbella FA, Aquino JL, Stefani-Nakano S, Artifon EL, Sakai P, Crema $E$, et al. Treatment of achalasia: lessons learned with Chagas' disease. Dis Esophagus. 2008;21(5):461-7.

11. Orringer MB. Marshall B, lannettoni MD. Tranhiatal esophagectomy: clinical experience and refinements. Ann Surg. 1999;230(3):392400; discussion 400-3.

12. Câmara-Lopes LH. Transposição retroesternal do estômago para anastomose esôfago-gástrica cervical, após esofagectomia subtotal [nota prévia]. Centro Médico de Ribeirão Preto; 1955

13. Ferreira-Santos R. Tratamento cirúrgico da aperistalse esofágica (megaesôfago) [dissertação]. Ribeirão Preto: Universidade de São Paulo, Faculdade de Medicina de Ribeirão Preto; 1965.

14. Ferreira EAB, Paula RA, Branco PD, Raia AA. Esophagectomy followed by esofagogastroplasty through the posterior mediastinum without toracotomy. Chir Gastroent. 1976;10:34750 .
15. Pinotti HW. Novas perspectives da execução de esofagectomias evitando as toracotomias. Arq Gastroenterol. 1977;14(2):93-8.

16. Pinotti HW, Zilberstein B, Pollara W, Raia A. Esophagectomy without thoracotomy. Surg Gynecol Obstet. 1981;152(3):344-6.

17. Pinotti HW, Cecconello I, da Rocha JM, Zilberstein B. Resection for achalasia of the esophagus. Hepatogastroenterol. 1991;38(6):4703.

18. Pinotti HW, Habr-Gama A, Cecconello I, Felix VN, Zilberstein B. The surgical treatment of megaesophagus and megacolon. Dig Dis. 1993;11(4-5):206-15.

19. Aquino JLB. Tratamento do megaeôfago pela mucosectomia com conservação da túnica muscular esofágica por via cervicoabdominal [tese]. Campinas: Universidade de Campinas, Faculdade de Ciências Médicas; 1996

20. Aquino JLB, Reis Neto JA, Muraro CLPM, Camargo JGT Mucosectomia esofágica no tratamento do megaesôfago avançado: análise de 60 casos. Rev Col Bras Cir. 2000;27(2):107-13.

21. Aquino JLB, Tarufi MJ, Martins RE, Castilho MV. Avaliação tardia da mucosectomia esofágica: análise de 42 pacientes com megaesôfago avançado. Rev Col Bras Cir. 2005;32(Supl):77.

22. Rocha JM, Cecconello I, Ishioka S, Zilberstein B, Gama-Rodrigues JJ, Pinotti HW. Gastrite de refluxo alcalino em gastroplastia. ABCD Arq Bras Cir Dig. 1987;2(2):64-7.

23. Rocha JRM, Cecconello I, Zilberstein B, Sallum RAA, Saika P, Ishioka $S$, et al. Esôfago de Barrett no coto esofagiano após esofagectomia subtotal com esofagogastroplastia cervical. Rev Hosp Clin Fac Med Univ São Paulo. 1992;47(2):69-70.

24. Oberg S, Johansson J, Wenner J, Walther B. Metaplastic columnar mucosa in the cervical esophagus after esophagectomy. Ann Surg 2002;235(3):338-45

25. da Rocha JR, Ribeiro U Jr, Sallum RA, Szachnowicz S, Cecconello I. Barrett's esophagus (BE) and carcinoma in the esophageal stump (ES) after esophagectomy with gastric pull-up in achalasia patients: a study based on 10 years follow-up. Ann Surg Oncol. 2008;15(10):2903-9.

26. da Rocha JR, Ribeiro U, Cecconello I, Sallum RA, Takeda F, Nasi A, et al. Gastric secretory and hormonal patterns in end-stage chagasic achalasia. Dis Esophagus. 2009;22(7):606-10.

27. Okuyama M, Motoyama S, Maruyama K, Sasaki K, Sato Y, Ogawa J. Proton pump inhibitors relieve and prevent symptoms related to gastric acidity after esophagectomy. World J Surg. 2008;32(2):24654. 
28. Terra Júnior JA, Terra GA, Silva AA, Crema E. Evaluation of anatomical and functional changes esophageal stump of patients with advanced megaesophagus submitted to subtotal laparoscopic esophagectomy. Acta Cir Bras. 2012;27(9):650-8.

29. Ministério da Saúde. Secretaria de Vigilância em Saúde. Consenso brasileiro em doença de chagas. Rev Soc Bras Med Trop. 2005;38 Suppl 3:7-29.

30. Gomes YM, Lorena VMB, Luquetti AO. Diagnosis of Chagas disease: what has been achieved? What remains to be done with regard to diagnosis and follow up studies? Mem Inst Oswaldo Cruz. 2009;104(Suppl 1):115-21

31. Britto CC. Usefulness of PCR-based assays to assess drug efficacy in Chagas disease chemotherapy: value and limitations.( Mem Inst Oswaldo Cruz. 2009;104 (Suppl 1):122-35.

32. Batista Neto J, Fontan AJ, Nepomuceno MC, Lourenço LG, Ribeiro LT, Ramos CP. Esofagectomia trans-hiatal no tratamento do megaesôfago chagásico avançado. Rev Col Bras Cir. 2003;30(3):230-7.

33. Abate E, DeMeester SR, Zehetner J, Oezcelik A, Ayazi S, Costales $J$, et al. Recurrence after esophagectomy for adenocarcinoma: defining optimal follow-up intervals and testing. J Am Coll Surg. 2010;210(4):428-35.

34. da Rocha JR, Cecconello I, Ribeiro U Jr, Baba ER, Safatle-Ribeiro $A V$, Iriya $K$, et al. preoperative gastric acid secretion and the risk to develop Barrett's esophagus after esophagectomy for chagasic achalasia. J Gastrointest Surg. 2009;13(11):1893-8; discussion 18989.

35. Yamamoto $S$, Makuuchi $H$, Shimada $H$, Chino O, Nishi T, Kise $Y$, et al. Clinical analysis of reflux esophagitis following esophagectomy with gastric tube reconstruction. J Gastroenterol. 2007;42(5):3425.

36. Yuasa N, Sasaki E, Ikeyama T, Miyake H, Nimura Y. Acid and duodenogastroesophageal reflux after esophagectomy with gastric tube reconstruction. Am J Gastroenterol. 2005;100(5):1021 7.
37. Park CH, Lee Jl, Choi S, Ko KP. A flow visualization model of duodenogastric reflux after esophagectomy with gastric interposition. J Cardiothoracic Surg. 2013;8:192.

38. Hölscher AH, Voit $H$, Buttermann $G$, Siewert JR. Function of the intrathoracic stomach as esophageal replacement. World J Surg. 1988;12(6):835-44

39. Gutschow CA, Collard JM, Romagnoli R, Michel JM, Salizzoni M, Hölscher AH. Bile exposure of the denervated stomach as an esophageal substitute. Ann Thorac Surg. 2001:71(6):1786-91.

40. Shibuya S, Fukudo S, Shineha R, Miyasaki S, Miyata G, Sugawara $\mathrm{K}$, et al. High incidence of reflux esopagitis observed by routine endoscopic examination after gastric pull-up esophagectomy. World J Surg. 2003;27(5):580-3.

41. Sharma P, McQuaid K, Dent J, Fennerty MB, Sampliner R, Spechler $S$, et al. A critical review of the diagnosis and management of Barrett's esophagus: the AGA Chicago Workshop. Gastroenterology. 2004;127(1):310-30.

42. Sharma P. Barrett's esophagus. N Eng J Med. 2009;361:2548-56.

43. Gutschow CA, Vallböhmer D, Stolte M, Oh D, Danemberg K, Danenberg $P$, et al. Adenocarcinoma developing in de novo Barrett's mucosa in the remnant esophagus after esophagectomy: clinical and molecular assessment. Dis Esophagus. 2008;21(3):E68

Received on: 15/11/2014

Accepted for publication: 20/01/15

Conflict of interest: none.

Source of funding: none.

\section{Mailing address:}

Celso de Castro Pochini

E-mail: celsopochini@gmail.com 